\title{
PENGETAHUAN HUKUM KONSTITUSI MENJADI ILMU HUKUM KONSTITUSI
}

\author{
Astim Riyanto ${ }^{1}$
}

\begin{abstract}
Knowledge of constitution intensively have emergedsincethe4thcentury BC. It begins with an investigation by Aristotle (384-322 BC) of the constitution (politeia)of158 city state (polis) of 186 city state (polis) in ancient Greece thatd ebuted from the 6th century $B C$ to the century to- $2 B C$. The results of the investigation Aristotle was stated in his Politica (Politics). Knowledge of the constitution changed to introduction to study of the law of constitution by Prof. Albert Venn Dicey (1835-1922) stated in his book An Introduction to The Study of The Law of The Constitution (1885). In the year 2007 by Prof.Dr.Drs.Astim Riyanto,SH,MH. (born 1949) in front of an academician community in an university in Indonesia, which poured in a paper, declared the law of constitution to be science of the law of the constitution. Declaration the law of the constitution to be science of the law of the constitution led by expert of Indonesia Constitutional Law Prof.Dr.R.Sri Soemantri Martosoewignjo,SH.
\end{abstract}

Keywords: constitution, introduction to study of constitutional law and constitutional jurisprudence

\begin{abstract}
Abstrak
Pengetahuan konstitusi (constitution) secara intensif telah muncul sejak abad ke-4 sebelum Masehi. Hal itu dimulai dengan penyelidikan oleh Aristoteles/Aristotle (384-322 sebelum Masehi) mengenai konstitusi (politeia) terhadap 158 negara kota (polis) dari 186 negara kota (polis) di zaman Yunani kuno yang berjaya dari abad ke-6 sebelum Masehi sampai dengan abad ke-2 sebelum Masehi. Hasil penyelidikan Aristoteles/Aristotle tersebut dituangkan dalam bukunya Politica (Politics). Pengetahuan konstitusi berubah menjadi pengantar studi hukum konstitusi oleh Prof. Albert Venn Dicey (1835-1922) yang dituangkan dalam bukunya An Introduction to Study of The Law of The Constitution (1885). Pada tahun 2007 oleh Astim Riyanto di depan suatu komunitas akademisi di suatu universitas di Indonesia, yang dituangkan dalam suatu makalah, dideklarasikan hukum konstitusi (the law of the constitution) menjadi ilmu hukum konstitusi (science of the law of the constitution). Pendeklarasian hukum konstitusi menjadi ilmu hukum konstitusi dipimpin oleh pakar Hukum Tata Negara Indonesia Sri Soemantri Martosoewignjo.
\end{abstract}

${ }^{1}$ Penulis adalah Guru Besar Ilmu Hukum Tata Negara spesialisasi Hukum Konstitusi, Universitas Pendidikan Indonesia (UPI) bandung, dan Fakultas Hukum Universitas Pancasila, Jakarta. Alamat kontak: astimriyanto@yahoo.com. 
Kata kunci: konstitusi, pengantar studi hukum konstitusi, ilmu hukum konstitusi

\section{Pendahuluan}

Hukum Konstitusi (The Law of The Constitution) dilihat dari segi keilmuannya menjadi Ilmu Hukum Konstitusi (Science of The Law of The Constitution). Perjalanan Hukum Konstitusi dari segi keilmuannya dimulai dari tonggak sejarah pertama Ilmu Hukum Konstitusi pada abad ke-4 sebelum Masehi (SM) di mana Aristoteles/Aristotle (384-322 SM) melakukan penyelidikan konstitusi (politeia) 158 negara kota (polis, city state, stad staat) dari 186 negara kota di Yunani kuno. Dalam bukunya itu disebutkan namanama negara kota (polis) di antaranya Athena, Sparta, Crete, Carthage, Thebes, Eretria, Aegina, Miletus, Cnidus, Chios, Delphi, Larissa, Amphipolis, Ambracia, Apollonia, Argos, Abydos, Epidamnus, dan Chalcis. Hasil penyelidikan beliau kemudian dimuat dalam bukunya Politica (Politics) yang terbit abad ke-4 SM. ${ }^{2}$ Tonggak sejarah kedua Ilmu Hukum Konstitusi pada akhir paruh kedua abad ke-19 di mana Prof. Albert Venn Dicey (1835-1922) menuangkan hasil pemikirannya mengenai Hukum Konstitusi dalam bukunya An Introduction to Study of The Law of The Constitution yang untuk pertama kali terbit tahun 1885. ${ }^{3}$ Tonggak sejarah ketiga Ilmu Hukum Konstitusi pada awal paruh pertama abad ke-21 di mana Prof. Dr. Drs. Astim Riyanto, SH, MH. (lahir 1949) mendeklarasikan "Hukum Konstitusi Sebagai Suatu Ilmu"yang berdiri sendiri dalam makalah yang berjudul "Hukum Konstitusi Bagian Dari Hukum Tata Negara" di depan suatu komunitas akademisi di suatu Universitas di Indonesia tangga 16 Agustus 2007. ${ }^{4}$ Kemudian, dipertegas dengan makalah Pidato Pengukuhan Jabatan GuruBesar dalam Bidang Ilmu Hukum Tata Negara spesialisasi Ilmu Hukum Konstitusi tanggal 22 Oktober2 $008^{5}$ berjudul "Hukum Konstitusi Sebagai Suatu Ilmu". Ilmu Hukum Konstitusi adalah ilmu hukum yang mempelajari konstitusi. Di sini "konstitusi" ditulis dengan huruf $\mathrm{k}$ kecil yang berarti konstitusi (constitution) dalam arti

2 Lihat Aristotle, "Politics", Translated by Sir Ernest Barker, Revised with an Introduction and Notes by R.F.Stalley, First Published 1995, Reissued 1998, (New York: Oxford University Press Inc., 1998).

3 Lihat Prof.Albert Venn Dicey, "An Introduction to Study of The Law of The Constitution", Tenth Edition (First Edition 1885), English Language Book Society and Macmillan, London, 1952.

${ }^{4}$ Lihat Dr.Astim Riyanto,SH,MH., Hukum Konstitusi Bagian Dari Hukum Tata Negara, Makalah, Dipresentasikan di depan komunitas akademisi Fakultas Pendidikan Ilmu Pengetahuan Sosial (FPIPS) Universitas Pendidikan Indonesia (UPI) dalam rangka Dr.Astim Riyanto,SH,MH. memperoleh Jabatan Guru Besar Tetap dalam Bidang Ilmu Hukum Tata Negara spesialisasi Hukum Konstitusi, FPIPS UPI, Bandung, 6 Agustus 2007.

${ }^{5}$ Lihat Dr.Drs.Astim Riyanto,SH,MH., Hukum Konstitusi Sebagai Suatu Ilmu, Pidato Pengukuhan Dr.Astim Riyanto,SH,MH. sebagai Guru Besar dalam Bidang Ilmu Hukum Tata Negara Spesialisasi Ilmu Hukum Konstitusi pada Fakultas Pendidikan Ilmu Pengetahuan Sosial (FPIPS) Universitas Pendidikan Indonesia (UPI) di Bandung tanggal 22 Oktober 2008 
luas, bukan "Konstitusi" ditulis dengan huruf K besar yang berarti Konstitusi (Constitution) dalam arti sempit yang bersinonim dengan Undang-Undang Dasar (Grondwet dan Grundgesetz). Dilihat dari segi obyek ilmu hukum konstitusi, maka ilmu hukum konstitusi adalah ilmu hukum yang mempunyai obyek materia konstitusi dan mempunyai obyek forma hukum dasar termasuk Undang-Undang Dasar sebagai hukum dasar tertulis (written fundamental law, written basic law) yang menjadi hukum dasar tertulis tertinggi dari tata hukum nasional (national legal order) suatu negara.

Apabila tonggak-tonggak sejarah pertama, kedua, dan ketiga Ilmu Hukum Konstitusi dituangkan dalam suatu gambar dapat dilihat di bawah ini:

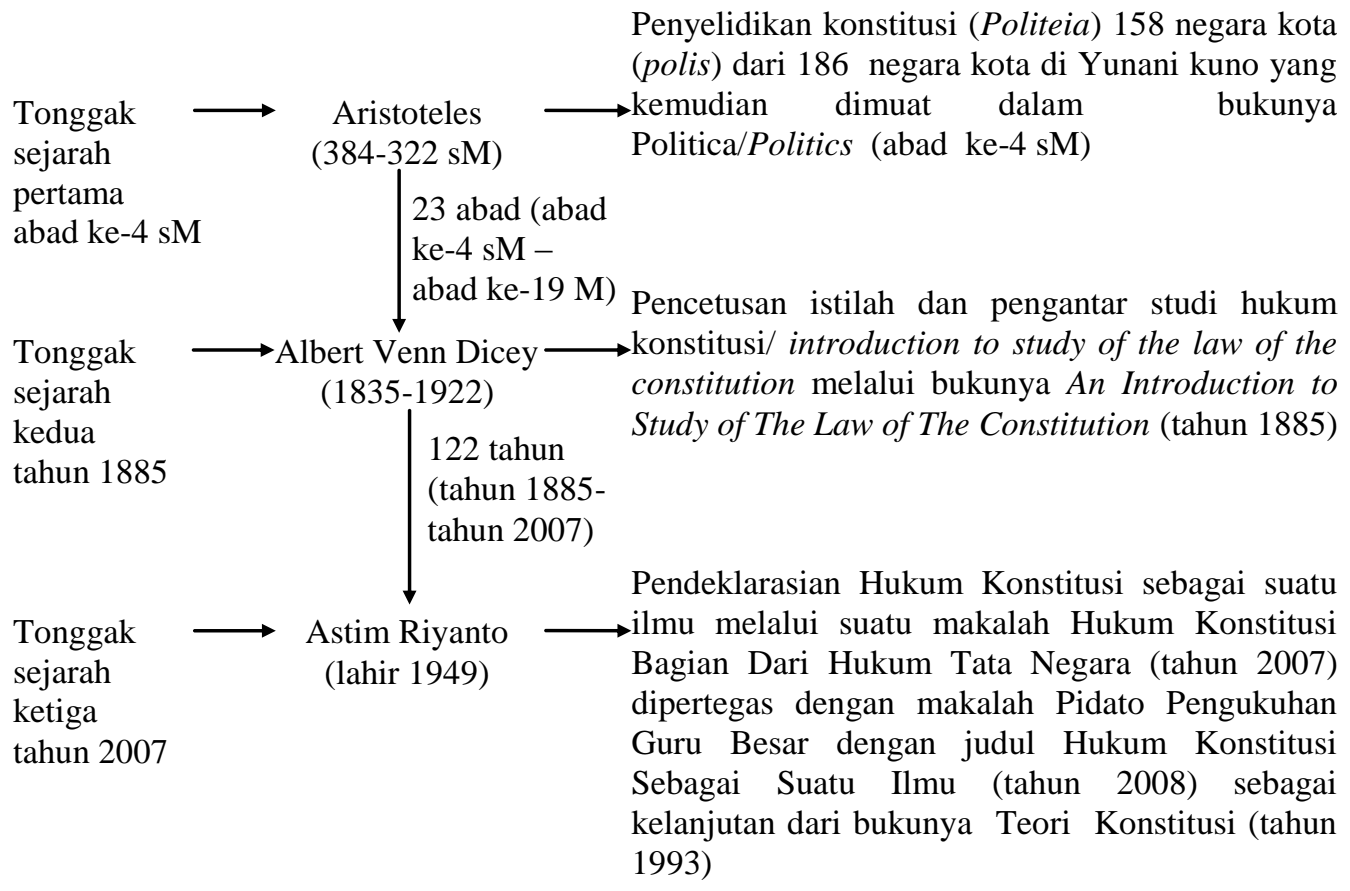

Gambar 1.1Tonggak-tonggak sejarah Ilmu Hukum Konstitusi

Dengan lahirnya ilmu baru Ilmu Hukum Konstitusi, maka secara klasik Ilmu Hukum Tata Negara (HTN) dalam arti luas menjadi memiliki tiga cabang ilmu, yaitu Ilmu Hukum Konstitusi, Ilmu Hukum Tata Negara (HTN) dalam arti sempit, dan Ilmu Hukum Tata Usaha Negara (HTUN)/IlmuHukum Administrasi Negara (HAN).

Hukum Konstitusi dilihat dari segi peraturannya menjadi Peraturan Hukum Konstitusi (Regulation of The Law of The Constitution). Peraturan (atau lengkapnya peraturan perundang-undangan) Hukum Konstitusi mengatur negara dari segi organisasinya. Dengan perkataan lain, Peraturan Hukum Konstitusi adalah peraturan hukum yang menetapkan dan mengatur organisasi negara dari suatu negara. Peraturan Hukum Konstitusi dalam bentuk peraturan tertulis dan bentuk peraturan tidak tertulis.Pada awalnya, Peraturan Hukum Konstitusi seperti juga peraturan hukum pada umumnya tumbuh dari peraturan 
tidak tertulis. Peraturan hukum tidak tertulis tadi, menurut Prof. Kenneth C. Wheare, bisa dalam wujud peraturan kebiasaan (usages rules), peraturan kesepahaman/kesepakatan (understandings rules), peraturan adat istiadat (customs rules), dan peraturan konvensi (conventions rules) ${ }^{6}$ terutama dalam lapangan ketatanegaraan. Peraturan hukum konstitusi tidak atau belum tertulis ini sering disebut dengan peraturan hukum konstitusi dalam arti material. Peraturan hukum konstitusi dalam arti material ini sudah berjalan di negaranegara kota (polis) di zaman Yunani kuno sebagaimana dapat dicermati dari laporan penyelidikan konstitusi oleh Aristoteles/Aristotle yang dituangkan dalam bukunya Politica (Politics). Dizaman Yunani kuno (abad ke-6 SM sampai dengan abad ke-2 SM) konstitusi dikenal dengan nama politeia. Dizaman Romawi (abad ke-2 SM sampai dengan abad ke-5 M) dikenal dengan nama Lex Regia, dan di Abad Pertengahan (abad ke-5 M sampai dengan abad ke-15 M) dikenal dengan nama Leges Fundamentalis. Hingga saat inipun peraturan hukum konstitusi tidak tertulis dalam arti unwritten constitution/nondocumentary constitution masih dianut oleh sejumlah negara seperti Inggris, Swedia, Kanada, Selandia Baru, Spanyol, Israel, dan Bhutan.

Adapun peraturan hukum konstitusi tertulis dalam arti documentary constitution baru ada sejak adanya Konstitusi Amerika Serikat 1787. Selanjutnya, negara-negara modern lain hingga saat ini menjadikan Konstitusi Amerika Serikat 1787 itu sebagai model Konstitusi dinegaranya. Umpamanya, Konstitusi Perancis1791, Konstitusi Spanyol 1812, Konstitusi Norwegia 1814, Undang-Undang Dasar Belanda 1814, Konstitusi Italia 1848, Konstitusi Swedia 1866, Konstitusi Swiss (Switzerland) 1874, Konstitusi Usmaniah1876, Konstitusi Jepang 1889, Konstitusi Rusia1918, Konstitusi Weimar Jerman 1919, Konstitusi Finlandia 1919, Konstitusi Austria1920, Konstitusi Cekoslovakia 1920, Konstitusi Hongaria1920, Konstitusi Yugoslavia 1921, Konstitusi Belgia 1921, Konstitusi Uni Soviet 1924,Konstitusi Turki1924, Konstitusi Libanon 1926, Konstitusi Portugal 1933, Undang-Undang Dasar Indonesia 1945, Konstitusi Burma 1947, Konstitusi Jerman Barat 1948, Konstitusi Sri Langka 1948, dan Konstitusi India 1950. Negara-negara modern yang mungkin lahir kemudian pun kemungkinan akan menjadikan Konstitusi Amerika Serikat 1787 tadi sebagai model Konstitusi dinegaranya.

\section{Mata Rantai Keilmuan Hukum Konstitusi}

Pemikiran hukum konstitusi sebagai peraturan yang membentuk negara terus bergulir sejak zaman Yunani kuno ke zaman Imperium Romawi ke Abad Pertengahan ke zaman Rasionalisme ke zaman Modern kemudian ke zaman Posmodern. Hukum konstitusi dalam arti material dan dalam arti unwritten constitution/non-documentary constitution secara umum berakhir sejak

${ }^{6}$ Lihat dan bandingkan Prof. Kenneth C. Wheare, "Modern Constitutions", Third Impression, First Published 1951, (London, New York, Toronto: Oxford UniversityPress, 1975), hal. 1. 
disahkan Konstitusi Amerika Serikat 1787. Konstitusi Amerika Serikat sebagai konstitusi modern ini terlahir sebagai dampak ikutan dari dimulainya zaman modern sejak Revolusi Amerika Serikat 1776 dan sejalan dengan Revolusi Perancis 1789 yang disusul Revolusi Rusia 1917 dan di kemudian hari muncul Revolusi Indonesia 1945. Sejak Konstitusi Amerika Serikat ini disahkan/ ditetapkan, maka terlahir hukum konstitusi sebagai peraturan dalam arti written constitution/documentary constitution. Dengan terlahirnya written constitution/documenttary constitution tidak berarti unwritten constitution/nondocumentary constitution hilang sama sekali, melainkan di beberapa negara unwritten constitution/non-documentary constitution masih tetap menganutnya seperti di Inggris, Swedia, Kanada, Selandia Baru, Spanyol, Israel, dan Bhutan.

Terhadap fenomena adanya HukumKonstitusi sebagai ilmu dalam setiap zaman terdapat para pemikir mengenai keilmuan Hukum Konstitusi. Secara keseluruhan para pemikir Hukum Konstitusi dari segi keilmuan dari setiap zaman tergolong kecil jumlahnya. Pada umumnya, di samping Hukum Konstitusi dimaknai sebagai peraturan di sisinya berjalan pemikiran Hukum Konstitusi sebagai pengetahuan yang kemudian menjadi ilmu.

Buku-buku, artikel konseptual, atau artikel khusus (special article),dan karya ilmiah lainnya yang masih berupa pengetahuan konstitusi, yaituAn Introduction to Study of The Law of The Constitution (Albert venn Dicey, 1885); Konvensi Ketatanegaraan (Bagir Manan, 1987); Modern Constitutions (W.F.Dodd, 1909); De Beproefde Grondwet, Rede Uitgesproken bij de Aanvaarding van het Ambt van Buitengewoon Hoogleraar in het Staats en Administratiefrecht and de Rijkuniversiteit, over het begrip Constitutie (J.G. Steenbeek, 1921); The New Constitutions (H.L. MacBrain and L. Rogers, 1922); Federal and Unified Constitution (A.P. Newton, 1923); The Law and The Constitution (Sir William Ivor Jennings, 1933); The English Constitution (Walter Bagehot, 1936); Constitutional Law: An Outline of the Law and Practice of the Constitution, Including Central and Local Government, the Citizen and the State Adminisrative Law (E.C.S. Wade and G. Godfrey Philips, 1936); Modern Constitution Since 1787 (J.A. Hawgood, 1939); Understanding the Constitution (Edward S. Corwin, 1949); The Origins of Modern Constitutionalism (Francis D. Wormuth, 1949); Constitutional Government and Democracy: Theory and Fractice in Europe and America (Carl Joachim Friedrich, 1950); Proklamasi dan Konstitusi Republik Indonesia (Muhammad Yamin, 1954); American Constitutional Law (Bernard Schwartz, 1955); Modern Constitutions (Russel F. Moore, 1957); Hak-hak Dasar Konstitusi Demokrasi Modern (Soewardi, 1957); Naskah-Persiapan Undang-Undang Dasar 1945 (Muhammad Yamin, 1959); Modern Political Constitutions An Introduction to the Comparative Study of Their History and Existing Form (C.F. Strong, 1960); A Contemporary on the Constitution of the United States, The Power of Government (Bernard Schwartz, 1963); The Decline of Constitutional Democracy in Indonesia (Herbert Feith, 1964); Constitutions of Nations: Volume I-Africa (Amos J. Peaslee, 1965); Constitutionalism : Ancient and Modern (Charles Howard McIlwan, 1966); Sekitar Proklamasi, Konstitusi, dan Dekrit Presiden (Harun Al Rasjid, 1966); Modern Constitutions (Kenneth 
C. Wheare, 1966); Dinamika Tata Negara Indonesia Kompilasi Aktual Masalah Konstitusi, Dewan Perwakilan, dan Sistem Kepartaian (Yusril Ihza Mahendra, 1966); De Beproefde Grondwet (J.G. Steenbeek, 1967); Constitutions and Constitutionalism (William G. Andrews, 1968); Constitutions of Nations: Volume III-Europe (Amos J. Peaslee, 1968); Het Constitutioneel Recht van het Koninkrijk der Nederlanden (P.J.Oud, 1970); Constitutions of Nations: Volume IV-The Americas (Amos J. Peaslee, 1970); Membina Tata Kehidupan Politik Berlandaskan Undang-Undang Dasar 1945 (Soediman Kartohadiprodjo, 1970); Constitutional Theory (Geoffrey Marshall, 1971); American Constitutional Law (Rosco J. Trosolini and Martin Shapiro, 1971); Comparative Constitutions (Leslie Wolf Phillips, 1972); Over het Verschijnsel Grondwet (H. Th.J.F. van Maarseveen en G.F.M. van der Tang, 1973); Piagam Nabi Muhammad SAW: Konstitusi Negara Tertulis yang Pertama di Dunia (Zainal Abidin Ahmad, 1973); Constitutions of Nations (Amos J. Peaslee, (Editor), 1974); Tiga Undang-Undang Dasar (H.A.G. Pringgodigdo, 1974); Written Constitutions, A Computerized Comparative Study (Henc van Maarseveen and Ger van der Tang, 1978); The New Soviet Constitution of 1977: Analysis and Text, Kings Court Communications (Robert Sharlet, 1978); Comparative Constitutional Law (Mauro Cappelletti and William Cohen, 1979); Five Constitutions, Contrasts, and Comparisons (S.E. Finer, 1979); Les Constitutions de La France Depuis 1789 (Jacques Godechot, 1979); Susunan Pembagian Kekuasaan Menurut Undang-Undang Dasar 1945 (Mohammad Kusnardi dan Bintan Regen Saragih, 1980); Constitutional Law, Cases and Materials (Gerald Gunther, 1980); Sekitar Pancasila, Proklamasi \& Konstitusi (Safiyudin Sastrawijaya, 1980); Different Concepts of Modern Constitutions (Artikel Konseptual, Naoki Kobayashi, 1984); Penetapan UUD Dilihat Dari Segi Ilmu Hukum Tata Negara Indonesia (J.C.T. Simorangkir, 1984); Constitutions of Nations: Volume II-Asia, Australia and Oceania (Amos J. Peaslee, 1985); Hukum Tatanegara Negara Kesatuan Republik Indonesia Berdasarkan Pancasila dan Undang-Undang Dasar 1945 Adalah Negara Hukum (Soehino, 1985); Konstitusi Jepang (Slamet Prajudi Atmosudirdjo et al., 1986); Konvensi Ketatanegaraan (Bagir Manan, 1987); Kedudukan Lembaga-lembaga Negara dan Hak Menguji Menurut UUD 1945 (Muhammad Ridhwan Indra, 1987); Constitutional and Administrative Law (O. Hood Phillips, 1987); Prosedur dan Sistem Perubahan Konstitusi (R. Soemantri Martosoewignjo, 1987); Dewan Konstitusi di Perancis (Bagir Manan, Jurnal, Artikel Konseptual, 1988); Undang-Undang Dasar 1945 Sebagai Karya Manusia (Muhammad Ridhwan Indra, 1990); Undang-Undang Dasar, Pedoman Penghayatan dan Pengamalan Pancasila (Ketetapan MPR No. II/MPR/1978, Garis-garis Besar Haluan Negara (Ketetapan MPR No. II/MPR/1988) (BP-7, 1991); Fungsi Ganda Konstitusi, Suatu Jawaban Alternatif Tentang Tepatnya Undang-Undang Dasar 1945 Mulai Berlaku, 1991); Membudayakan Undang-Undang Dasar 1945 (Padmo Wahjono, 1991); Konstitusi \& Demokrasi Beberapa Pemikiran Tentang Hukum (Soehardjo Sastrosoehardjo, 1991); Pemikiran Rousseau Dalam Konstitusi Amerika Serikat (Albertina Baramuli, 1992); Handbook in Teaching Practical Law 
Module a Primer on Introduction to the Study of the 1987 Constitution and Government (Carmelo V. Sison and Luz D. Pagulayan, 1992); Teori Konstitusi (Astim Riyanto, 1993); Susunan Ketatanegaraan Menurut UUD 1945 dalam Ketatanegaraan Indonesia dalam Kehidupan Politik Indonesia (R. Sri Soemantri Martosoewignjo, 1993); Ketatanegaraan Indonesia dalam Kehidupan Politik Indonesia 30 Tahun Kembali Ke UUD 1945 (R. Sri Soemantri Martosoewignjo, (Editor), 1993); Essential Constitutional Law (Andrew Beals, 1994); Gagasan Kedaulatan Rakyat dalam Konstitusi dan Pelaksanaannya di Indonesia (Jimly Asshiddiqie, 1994); Aspirasi Pemerintahan Konstitusional di Indonesia Studi Sosio-Legal Atas Konstituante 1956-1959 (The Aspiration for Constitutional Government in Indonesia: A Socio-Legal of the Indonesian Constituante 1956-1959) (Adnan Buyung Nasution, 1995); Piagam Madinah dan Undang-Undang Dasar 1945 Kajian Perbandingan Tentang Dasar Hidup Bersama Dalam Masyarakat yang Majemuk (Ahmad Sukardja, 1995); Pertumbuhan dan Perkembangan Suatu Negara (Bagir Manan, 1995); American Constitutional Interpretation (Walter F. Murphy, James E. Fleming, and Sotirios A. Barber, 1995); Unconstitutional Essays (Pacifico A. Agabin, 1996); Masalah Hubungan Antar-Lembaga Tinggi Negara dan Hak Asasi Manusia Berdasarkan UUD 1945 (Albert Hasibuan, Artikel Konseptual, 1996); Textbook on Constitutional and Administrative Law (Brian Thompson, 1997); Constitutionalism: Philosophical Foundations (Larry Alexander, (Editor), 1998); Konstitusi dan Kelembagaan Negara (Chairul Anwar, 1999); Implementasi Sistem Ketatanegaraan Menurut UUD 1945 (Dahlan Thaib, 1999); Tata Negara Baru Sistem Pemerintahan yang Demokratis dan Konstitusional (P.J. Suwarno, 1999); Demokrasi dan Konstitusi di Indonesia Studi Tentang Interaksi Politik dan Kehidupan Ketatanegaraan (Mohammad Mahfud MD., 2000); Prosedur Perubahan Konstitusi (Perubahan UndangUndang Dasar Negara RI 1945 dan Perbandingannya dengan Konstitusi Negara Lain (Taufiqurrochman, Disertasi, 2003; Teori dan Politik Konstitusi (Bagir Manan, 2004); Konstitusi \& Konstitutionalisme Indonesia (Jimly Asshiddiqie, 2005); Hukum Konstitusi dan Mahkamah Konstitusi (Abdul Mukhtie Fajar, 2006); Panduan Pemasyarakatan Undang-Undang Dasar Negara Republik Indonesia Tahun 1945 (Majelis Permusyawaratan Rakyat RI, 2006); Bedah Konstitusi Lewat Gambar Dinamika Konstitusi Indonesia (Hendarmin Ranadireksa, 2007); Dari Konstruksi Sampai Konstitusi Catatan Perjalanan A.M. Luthfi 1935-2005 (A.M. Luthfi, 2007); Sebuah Ideologi Perubahan Konstitusi (Budiman Tanuredjo, Harian Umum, Special Article, 2007); Pendidikan: Ketua MK: Pembentuk UU Bisa Dinilai Lecehkan UUD (Harian Umum, Berita, 2007); Kambing Hitam Itu Bernama UUD 1945 (Harian Umum, Berita, 2007); Kapita Selekta Hukum Konstitusi (Astim Riyanto, 2009); Legitimasi Perubahan Konstitusi Kajian Terhadap Perubahan UUD 1945 (Hardjono, 2009); Konstitusi adalah Dasar Hidup Bernegara (Harian Umum, Berita, 2009).

Diurutkan berdasarkan tahun terbit buku-buku atau bentuk tulisan lainnya mengenai konstitusi tersebut diatas, ternyatalah buku-buku itu terbit setelah tahun terbit buku karangan Prof. Albert Venn Dicey (1835-1922) yang 
berjudul An Introduction to Study of The Law of The Constitution (1885). Namun, kalau kita lihat judul-judul buku tersebut tidak ada yang berjudul atau membahas Studi Hukum Konstitusi (Study of The Law of The Constitution) apalagi yang berjudul atau membahas Ilmu Hukum Konstitusi (Science of The Law of The Constitution). Jadi, buku-buku yang terbit setelah buku An Introduction to Study of The Law of The Constitution (1885) terbit masih berupa pengetahuan konstitusi dan belum berupa hukum konstitusi sebagai suatu ilmu. Baru pada tahun 2007 oleh Prof. Dr. Drs. Astim Riyanto, SH, MH. (lahir 1949) di depan suatu komunitas akademisi di suatu Universitas di Indonesia, yang dituangkan dalam suatu makalah, dideklarasikan hukum konstitusi sebagai ilmu hukum konstitusi. Pendeklarasian pengetahuan hukum konstitusi menjadi ilmu hukum konstitusi dipimpin oleh pakar Hukum Tata Negara Indonesia Prof. Dr. R. Sri Soemantri Martosoewignjo, SH. Selanjutnya, pada tahun 2008 dipertegas dengan makalah pidato pengukuhan Dr. Astim Riyanto, SH, MH. sebagai Guru Besar (Profesor) dalam Bidang Ilmu Hukum Tata Negara spesialisasi Ilmu Hukum Konstitusi yang berjudul "Hukum Konstitsi Sebagai Suatu Ilmu". Deklarasi itu hingga sekarang terus ditindak lanjuti dan di kembangkan. Dimasake depan Ilmu Hukum Konstitusi dapat menjadi cabang ilmu hukum normatify ang mapan berdampingan dengan ilmuilmu hukum normatif lain, sehingga ilmu-ilmu hukum normatif menjadi atau meliputi Ilmu Hukum Negara, Ilmu Hukum Konstitusi, Ilmu Hukum Tata Negara, Ilmu Hukum Tata Usaha Negara/Ilmu Hukum Administrasi Negara, Ilmu Hukum Pidana, Ilmu Hukum Perdata, dan Ilmu Hukum Internasional beserta ranting-ranting ilmu di dalamnya.

Dari segi pandangan historis keilmuan Hukum Konstitusi, dapat dipandang ke dalam tiga tahapan pandangan, yaitu pandangan keilmuan Hukum Konstitusi dari Aristoteles/Aristotle, pandangan keilmuan Hukum Konstitusi dari Albert Venn Dicey, dan pandangan keilmuan Hukum Konstitusi dari Astim Riyanto.

\section{Pandangan Keilmuan Hukum Konstitusi dari Aristoteles}

Dari sudut keilmuwan dapat dipandang di zaman Yunani kuno dapat dicatat Aristoteles/Aristotle (384-322 SM) tampil di samping sebagai filosof terkemuka jugasebagai ilmuwan terkemuka terutama dizamannya telah melakukan penyelidikan konstitusi terhadap 158 konstitusi negara kota (polis) dari186 negara kota (polis) yang adadi Yunani kuno. Hasil penyelidikan konstitusi tersebut beliau muat dalam delapan Book dalam bukunya yang berjudul Politica (Politics). Dalam bukunya itu, Aristoteles/Aristotle memaparkan dalam delapan Book, yaitu: Book I. TheHauseholdandThe City, Book II. Review of Constitutions, Book III. The Theory of Citizenship and Constiutions, Book IV. Actual Constitutions and Their Varieties, Book V. Causes of Factional Conflict and Constitutional Change, Book VI. Methods of Constructing Democracies and Oligarchies with a Special View to Their Greater Stability, Book VII. Political Ideals and Educational Principles, and Book VIII. The Training of Youth. 
Book I mencakup A. Associations (Chapters 1-2), B. The Association of the Household and its Different Factors (Chapters 3-13), (1. The Constituent Elementsof the Household (Chapter 3), 2. Slavery (Chapters 4-7), 3. Proverty and the Art of Acquisition (Chapters 8-11), 4. Marriage, Parenthood, and the General Management of the Household (Chapters 12-13)). Book II mencakup A. Constitutions in Theory (Chapters 1-8), (1. Plato's Republic (Chapters 1-5), 2. Plato's Laws (Chapter 6), 3. Phaleas of Chalcedon (Chapter 7), 4. Hippodamus ofMiletus (Chapter 8));B. Actual Constitutions which Approach the Ideal(Chapters 9-12) (1. The Spartan Constitution (Chapter 9), 2. The Cretan Constitution (Chapter 10), 3. The Carthaginian Constitution (Chapter 11), 4. Postscript on Other Legislators (Chapter 12)). Book III mencakup A. Citizenship (Chapters 1-5), B. Constitutions and Their Classification (Chapters 6-8), C. The Principles of Oligarchy and Democracy and the Nature of Distributive Justice (Chapters 9-13), D. Kingship and its Forms (Chapters 1418). Book IV mencakup A. Introductory (Chapters 1-2), B. The Varieties of the Main Types of Constitution especially Democracy, Oligarchy, and Constitutional Government or Polity (Chapters 3-10), C. The Type of Constitution which is Most Generally Practicable (Chapter 11), D. What Sort of Constitution is Desirable for What Sort of Civic Body? (Chapters 12-13), E. The Methods of Establishing Constitutions, - in Relation to the, Three Powers-Deliberative, Executive, and Judicial (Chapters 14-16). Book V mencakup:

1. TheGeneralCauses of Factional Conflict and Change in all Types of Constitution (Chapters 1-4);

2. Particular Causes of Conflict and Change in Democracies, Oligarchies, and Aristocracies (Chapters 5-7) (1. Democracies (Chapter 5), 2. Oligarchies (Chapter 6), 3. Aristocracies (Chapter 7));

3. Methods of Ensuring Constitutional Stability in the Three Previous Types of Constitution and More Generally (Chapters 8-9);

4. The Causes of Conflict and Change and the Methods of Ensuring Stability in Monarchies (Chapters 10-11);

5. The Chronology of Tyrannies and Criticisms of Plato's Account of Constitutional Change (Chapter 12).

Book VI mencakup:

1. The Construction of Democracies (Chapters 1-5);

2. The Construction of Oligarchies (Chapters 6-8).

Book VII mencakup:

1. Political Ideals: The Nature of the Highest Good and of the Best and Happiest Life (Chapters 1-3);

2. The Population, the Territory, the Natural Endowment of the Inhabitants, the Social Structure, and the Physical Planning of an Ideal City (Chapters 4-12) (1. The Population (Chapter 4), 2. The Territory (Chapters 5-6), 3. The Natural Endowment (Chapter 7), 4. The Social 
Structure (Chapters 8-10), 5. The Planning of the Central City (Chapters 11-12));

3. The General Principles of Education (Chapters 13-15) (1. The End and The Means (Chapter 13), 2. Education and Citizenship, Education for Leisure, and Education of Character (Chapters 14-15);

4. The Early Stages of Education (Chapters 16-17) (The Regulation of Marriage (Chapter 16), 2. The Nursery and the Infant School (Chapter 17)).

Book VIII mencakup:

1. The General Scheme of Training (Chapters 1-3):

2. Physical Training, or Gymnastics (Chapter 4);

3. The Aims and Methods of Education in Music (Chapters 5-7).

Apabila Book-Book c.q. Chapter-Chapter dalam buku Aristoteles/ Aristotle mengenai Politics (abad ke-4 sM) dituangkan dalam suatu gambar dapat dilihat berikut ini:

\begin{tabular}{|c|c|c|c|}
\hline $\begin{array}{l}\text { Aristotle } \\
84-322 \mathrm{sM})\end{array}$ & $\begin{array}{l}\text { Book III. The Theory of Citizenship } \\
\text { and Constitutions }\end{array}$ & $\begin{array}{l}-\mathrm{A} . \\
\text { B. } \\
\text { C. } \\
\text { D. } \\
\text { A. } \\
\text { B. }\end{array}$ & $\begin{array}{l}\text { Associations } \\
\text { The Association of the Household and Its Different } \\
\text { Factors } \\
\text { Constitutions in Theory } \\
\text { Actual Constitutions which Approach the Ideal } \\
\text { Citizenship } \\
\text { Constitutions and Their Classification } \\
\text { The Principles of Oligarchy and Democracy and the } \\
\text { Nature of Distributive Justice } \\
\text { Kingship and Its Forms } \\
\text { Introductory } \\
\text { The Varieties of the Main Types of Constitution } \\
\text { Especially Democracy, Oligarchy, and 'Constitutional } \\
\text { Government' or Polity }\end{array}$ \\
\hline
\end{tabular}




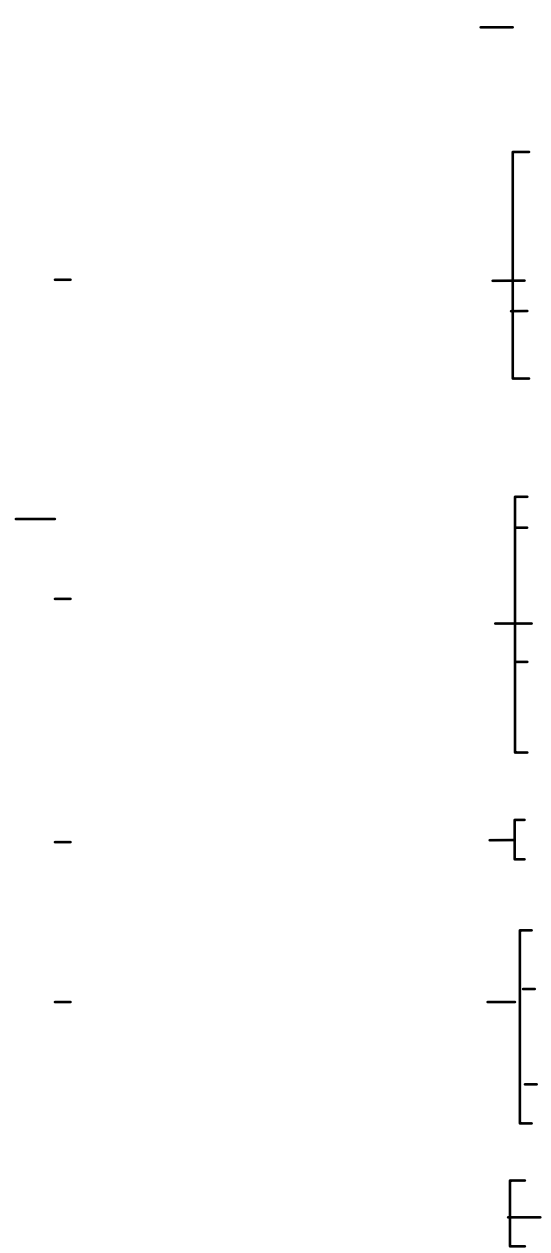

Gambar 1.2Ruang Lingkup Politics ( $4^{\text {th }}$ Age BC) dari Aristoteles

Dengan peranannya itu, maka Aristoteles/Aristotle dapat diposisikan sebagai perintis lahirnya Ilmu Hukum Konstitusi di kemudian hari, yang jadinya dewasa ini.

\section{Pandangan Keilmuwan Hukum Konstitusi dari Albert Venn Dicey}

Meskipun Hukum Konstitusi dari segiperaturanmerupakan peraturan hukum utama (primary law), peraturan hukum derajat tinggi (supreme law), atau peraturan hukum tertinggi (highest law), tetapi tidak banyak orang yang tertarik mengkajiHukumKonstitusidarisegi keilmuannya. Kebanyakan dari mereka lebih menekuni Hukum Konstitusi, baik dari segi politik, hukum, sosiologi maupun segi lainnya, padatingkatanpengetahuan konstitusi. Orang kedua setelah 23 abad sebelumnya dari penyelidikan konstitusi dari Aristoteles/Aristotle (384-322 SM) pada abad ke-4 sebelum Masehi yang tertarik memandang Hukum Konstitusi dari segi keilmuan adalah Prof. Albert 
VennDicey (1835-1922). Dalam menuang-kan pemikiran atau gagasan beliau terhadap keilmuan dari Hukum Konstitusi sebagai Pengantar Studi Hukum Konstitusi (Introduction to Study of The Law of The Constitution) beliau menyusun sebuah buku dengan judul An Introduction to Study of The Law of The Constitution yang terbit pertama kali tahun 1885.Dari judul buku tersebut, pada massa itu, beliau menyatakan pengetahuan konstitusi pada tingkatan Pengantar Studi Hukum Konstitusi. Dalam buku tersebut dipaparkan tiga Part, yaitu: Part I The Sovereignty of Parliament, Part II The Rule of Law, dan Part III The Connection Between The Law of the Constitution and the Conventions of the Constitution. Ketiga Part (PartI, PartII, dan Part III) tersebut mencakup 15 Chapter di dalamnya. Part I The Sovereignty of Parliament meliputi tiga Chapter, yaitu I. The Nature of Parliamentary Sovereignty. II. Parliament and non-Sovereign Law-Making Bodies. III. Parliamentary Sovereignty and Federalism. Part II. The Rule of Law meliputi 10 Chapter, yaitu IV. Rule of Law: It's Nature and General Applications. V. The Right to Personal Freedom, VI. The Right to Freedom of Discussion. VII. The Right of Public Meeting. VIII. Martial Law. IX. The Army. X. The Revenue. XI. The Responsibility of Ministers. XII. Rule of Law compared with Droit Administratif. XIII. Relation between Parliamentary Sovereignty and the Rule of Law. Part III The The Connection BetweenThe Law of the Constitution and the Conventions ofthe Constitution meliputi 2 Chapter, yaitu XIV. Nature of Conventions of Constitution. XV. The Sanction by which the Conventions of the Constitution are Enforced.

Apabila Part-Part c.q. Chapter-Chapter dalam buku Prof.Albert Venn Dicey mengenai An Introduction to Study of The Law of The Constitution (1885) dituangkan dalam suatu gambar dapat dilihat di bawah ini: 


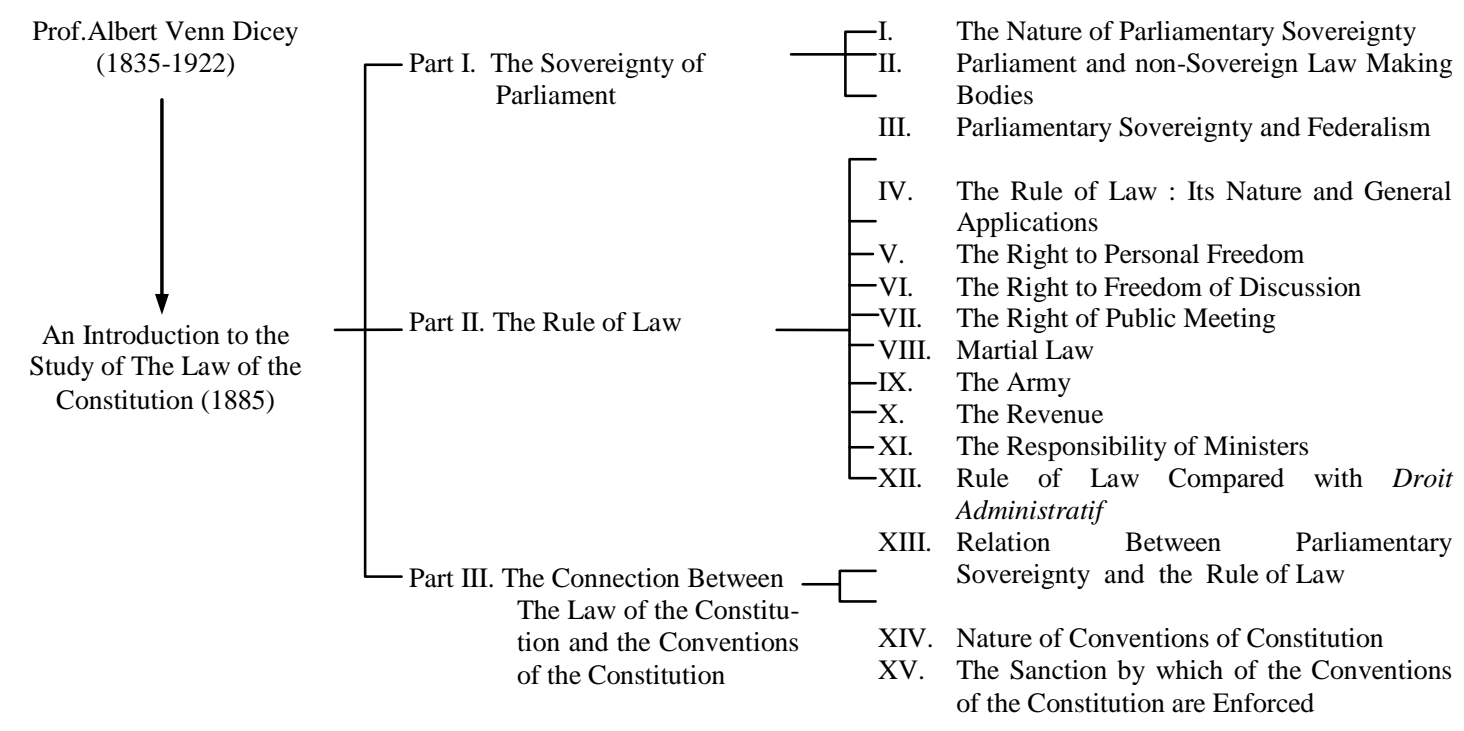

Gambar 1.3 Ruang Lingkup An Introduction to Study of The Law of The Constitution (1885) dari Albert Venn Dicey

Dengan peranannya itu, maka Prof.Albert Venn Dicey dapat diposisikan sebagai pencetus kearah terbentuknya Ilmu Hukum Konstitusi.

\section{Pandangan Keilmuwan Hukum Konstitusi dari Astim Riyanto}

Orang ketiga setelah 24 abad lebih dari Aristoteles/Aristotle pada abad ke-4 SM menerbitkan buku Politica (Politics) dan setelah 122 tahun dari Prof. Albert Venn Dicey pada abad ke-19 akhir menerbitkan buku An Introduction to Study of The Law of The Constitution yang terbit tahun 1885 yang tertarik pada keilmuan dari Hukum Konstitusi adalah seorang lulusan Magister Hukum Tata Negara spesialisasi Hukum Konstitusi dan Doktor Ilmu Hukum Tata Negara spesialisasi Hukum Konstitusi serta dosen Teori Konstitusi pada program sarjana dan dosen Hukum Konstitusi pada program pasca sarjana serta Guru Besar (Profesor) dalam Bidang Ilmu Hukum Tata Negara spesialisasi Ilmu Hukum Konstitusi. Dia adalah Prof.Dr.Drs. Astim Riyanto, SH,MH. (lahir 1949) dosen bidang Hukum dibeberapa Fakultas Hukum Universitas diIndonesia. Ketertarikannya kepada Hukum Konstitusi diawali dengan studi pada bidang Ilmu HukumTata Negara (Science of Constitutional Law) tahun 1991 dan menjadi dosen Teori Konstitusi pada program sarjana tahun 1993. Sebagai rasa perwujudan pertanggungjawabannya selaku pengampu mata kuliah tersebut, pengetahuannya mengenai konstitusi ia tuangkan dalam buku Teori Konstitusi pada tahun 1993 itu juga. Buku tersebut memaparkan seluruh aspek tentang konstitusi. Sebagai buku pada tataran pengetahuan konstitusi yang merupakan dasar-dasar konstitusi didalamnya tersebut memuat 27 bab, 
yaitu pendahuluan, pengertian konstitusi, sejarah konstitusi, perkembangan konstitusi, terjadinya konstitusi, hakikat konstitusi, paham konstitusi, konstelasi konstitusi, Negara konstitusi, kedudukan konstitusi, sistem konstitusi, kesadaran konstitusi, otoritas konstitusi, nilai konstitusi, fungsi konstitusi, tujuan konstitusi, studi konstitusi, bentuk konstitusi, klasifikasi konstitusi, jenis konstitusi, sifat konstitusi, substansi konstitusi, implementasi konstitusi, penafsiran konstitusi, pembentuk konstitusi, perubahan konstitusi, serta pengendalian danpengamanan konstitusi.

Hukum Konstitusi sebagai suatu ilmu oleh Dr.Astim Riyanto, SH, MH. Deklarasikan tangga 16Agustus 2007 pada saat ia menyajikan karya ilmiah berupa makalah didepan suatu komunitas akademisi di suatu Universitas di Indonesia dalam rangka memperoleh jabatan fungsional Guru Besar (Profesor) dalam Bidang Ilmu Hukum Tata Negara spesialisasi Ilmu Hukum Konstitusi. Makalah tersebut berjudul "Hukum Konstitusi Bagian Dari Hukum Tata Negara".

Dalam makalah "Hukum Konstitusi Bagian Dari Hukum Tata Negara" dipaparkan 5 Bab, yaitu: I. Pendahuluan, II. Aspek-aspek dalam Rumusan Hukum Konstitusi, III. Spektrum Lingkup Pengertian Konstitusi, IV. Konsepkonsep Hukum Konstitusi, dan V. Penutup. Bab I mencakup A. Pengertian Hukum Konstitusi; B. Arti Konstitusi dalam Konteks Hukum Konstitusi terdiriatas 1. Konstitusi dalam Arti Luas dan 2. Konstitusi dalam Arti Sempit; C. Sejarah dan Perkembangan Hukum Konstitusi terdiri atas 1. Kajian Keilmuwan Hukum Konstitusi Yunani Kuno, 2. Undang-Undang Bermuatan Konstitusi, 3. Konstitusi Modern, 4. Teori Konstitusi Sebagai Mata Kuliah, dan 5. Studi Hukum Konstitusi; D. Hukum Konstitusi sebagai Suatu Ilmu terdiri atas 1. Deklarasi Ilmu Hukum Konstitusi dan 2. Revolusi Ilmu Hukum Konstitusi; E. Tujuan Hukum Konstitusi terdiri atas 1.Hukum sebagai Tujuan Negara, 2. Konstitusi Menentukan Batas Wewenang Penguasa, dan 3. Tujuan Konstitusi Modern; dan F. Pendekatan Hukum Konstitusi terdiri atas 1. Hukum Itu Pasti; 2. Asas Fiksi Hukum, 3. Kadar Kepastian Hukum, 4. Pusaka-pusaka Hukum, 5. Teori Hukum Murni, 6. Pendekatan Hukum Dasar, dan 7. Pendekatan Lain. Bab II mencakup A. Hukum terdiriatas 1. Definisi Hukum, 2. Unsur-unsur Definisi Hukum; B. Hukum Tata Negara dan Hukum Biasa terdiri atas 1. Hukum Normatif dan Empiris, 2. HukumTata Negara dalam Arti Luas dan Sempit, dan 3. Obyek Kajian Ilmu Hukum Konstitusi; C. Hukum Konstitusi terdiri atas 1. Ilmu Hukum Konstitusi Mempelajari Konstitusi dan Hukum Dasar, 2. Materi Muatan Konstitusi sebagai Hukum Dasar, dan 3. Peraturan Perundang-undangan Konstitutif; D. Konstitusi terdiri atas 1. Konstitusi KajianIlmu Politik, 2. Konstitusi Kajian Ilmu Hukum c.q. Hukum Tata Negara i.c. Hukum Konstitusi, 3.Konstitusi Kajian Sosiologi c.q. Sosiologi Hukum, dan 4. Konstitusi Kajian Ilmu Lain. Bab III mencakup Spektrum Lingkup Pengertian Konstitusi terdiri atas A. Lingkup Pengertian Konstitusi dan B. Perbedaan Hukum Tata Negara dan Hukum Konstitusi. Bab IV mencakup A. Cakupan Konsep Hukum Konstitusi dan B. Lapangan Pengetahuan Hukum Konstitusi. 
Apabila Bab-bab dalam makalah Dr.Astim Riyanto, SH, MH. mengenai Hukum Konstitusi Bagian Dari Hukum Tata Negara (2007) dituangkan dalam suatu gambar dapat dilihat berikut ini:

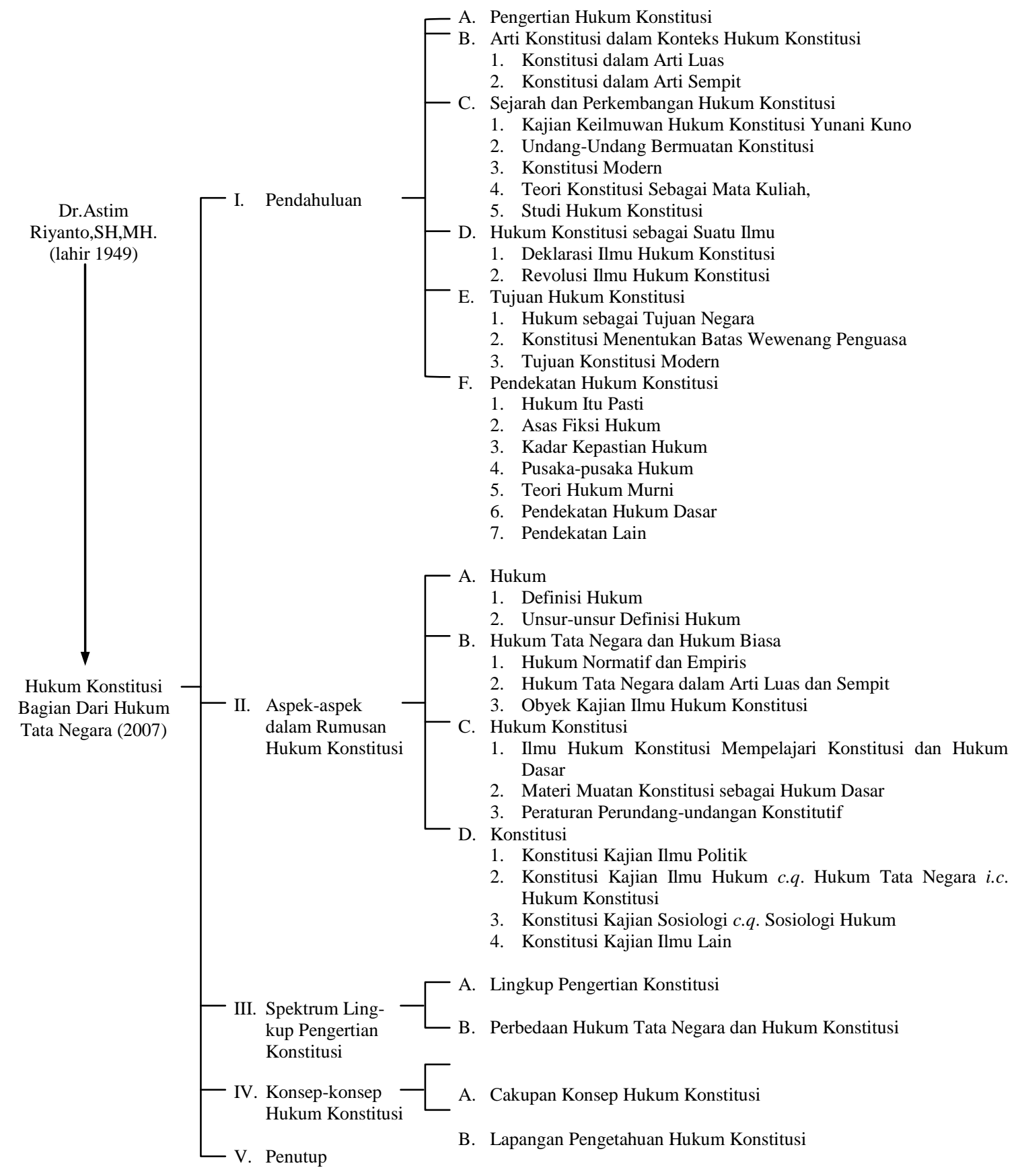

Gambar 1.4Ruang Lingkup Hukum Konstitusi Bagian Dari Hukum Tata Negara (2007) dari Astim Riyanto

Sebagai rasa pertanggungjawabannya untuk mewujudkan Hukum Konstitusi sebagai suatu ilmu, maka pada saat pengukuhannya sebagai Guru Besar (Profesor) dalam bidang Ilmu Hukum Konstitusi spesialisasi Hukum 
Konstitusi ia tampilkan makalah dengan judul "Hukum Konstitusi Sebagai Suatu Ilmu" pada Pidato Pengukuhan Jabatan Guru Besar Tetap Dr. Astim Riyanto, SH, MH.dalam Bidang Ilmu HukumTata Negara spesialisasi Ilmu Hukum Konstitusi pada suatu Universitas di Indonesia tanggal $22 \mathrm{O}$ ktober 2008.

Dalam makalah Pidato Pengukuhan Jabatan Guru Besar dalam Bidang Ilmu Hukum Tata Negara spesialisasi Hukum Konstitusi tersebut dipaparkan 9 Bab, yaitu : I. Pendahuluan, II. Persyaratan Suatu Ilmu Berdiri Sendiri, III. Ilmu Hukum Konstitusi Berdiri Sendiri, IV. Alasan Memadai Kehadiran Ilmu Hukum Konstitusi,V. Karakteristik HukumKonstitusi,VI.Implementasi Hukum Konstitusi, VII. Pengundangan dan Penyebarluasan Hukum Konstitusi, VIII. Peranan Ahli/Pakar Hukum Konstitusi, dan IX. Penutup. Bab II mencakup A. Persyaratan Suatu Ilmu dari segi Filsafat Ilmu terdiri atas 1. Ontologi Hukum Konstitusi, 2. Epistemologi Hukum Konstitusi, 3. Aksiologi Hukum Konstitusi; B. Persyaratan Ilmu Dari Segi Lain terdiri atas 1. Hukum Konstitusi Tersusun Sistematis, 2. Hukum KonstitusiUraiannyaLogis, 3. Hukum Konstitusi Bersifat Universal, 4. Hukum Konstitusi Mempunyai Pengertian Khusus, 5. Hukum Konstitusi Didukung Para Ahli/Pakar,danC. Ciri Pokok Ilmu Hukum Konstitusi. Bab III mencakup A. Hukum Konstitusi Memenuhi Persyaratan dan Ciri Pokok Suatu Ilmu Berdiri Sendiri, B. Perkembangan Ilmu Hukum Konstitusi Diikuti Bidang-Bidang Ilmu Di Dalamnya, dan C. Ilmu Hukum Konstitusi Rujukan Ilmu-ilmu Hukum Normatif lain. Bab IV mencakup A. Penyebab Yuridis Historis, B. Penyebab Yuridis Eksisten, dan C. Penyebab Yuridis Futuris. Bab V mencakup A. Karakteristik Hukum Konstitusi Sebagai Ilmu dan B. Karakteristik Hukum Konstitusi Sebagai Peraturan. Bab VI mencakup A. Hukum Konstitusi Membentuk Organisasi Negara, B. Kebutuhan Atas Lembaga Pengaman Konstitusi, dan C. Penegakan Negara Hukum Kesejahteraan. Bab VII mencakup A. Teori Promulgasi dan Notifikasi Hukum Konstitusi, B. Promulgasi Hukum Konstitusi, C. Notifikasi Hukum Konstitusi, D. Notifikasi Hukum Konstitusi Melalui Pendidikan, E. Pendidikan Hukum Konstitusi, dan F. Sumbangan Pendidikan Hukum Konstitusi. Bab VIII mencakup A. Maju Mundur Ilmu Hukum Konstitusi Tergantung Para Ahli/Pakar dan B. Hukum Konstitusi Memberikan Solusi Masalah Kenegaraan/ Ketatanegaraan.

Apabila Bab-Bab dalam makalah Prof.Dr.Drs.Astim Riyanto,SH,MH. mengenai Hukum Konstitusi Sebagai Suatu Ilmu (2008) dituangkan dalam suatu gambar dapat dilihat berikut ini: 


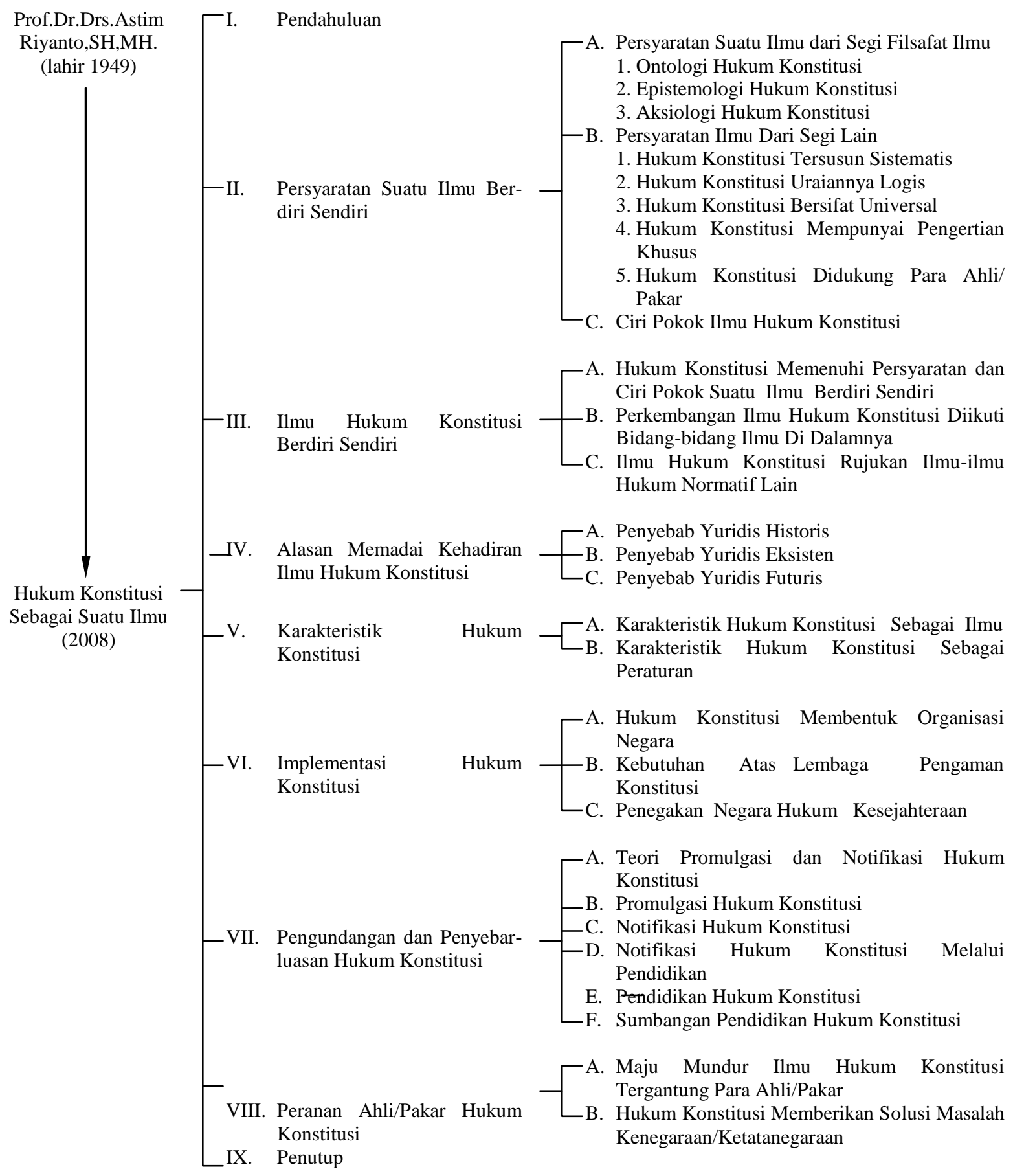

Gambar 1.5 Ruang Lingkup Hukum Konstitusi Sebagai Suatu Ilmu (2008) dari Astim Riyanto

Selanjutnya, ia menulis beberapa karya ilmiah di antaranya artikel "Notifikasi Hukum Konstitusi Melalui Pendidikan” yang dimuat pada Jurnal 
Hukum \& Pembangunan Tahun Ke-38 No. 1 Januari 2008 yang diterbitkan Fakultas Hukum Universitas Indonesia (UI) di Jakarta. Disusul tulisantulisannya yang lain mengenai hukum konstitusi.

Dengan peranannya itu, maka Prof. Dr. Drs. Astim Riyanto, SH, MH. dapat diposisikan sebagai pembentuk Ilmu Hukum Konstitusi.

\section{Perubahan Signifikan Hukum Konstitusi}

Ada dua kejadian signifikan atas hukum konstitusi, yaitu kejadian pengesahan Konstitusi modern pertama dan pendeklarasian Hukum Konstitusi sebagai suatu ilmu.

\section{Pengesahan Konstitusi Modern Pertama}

Dalam alinea keempat/terakhir Pembukaan Undang-Undang Dasar Negara Republik Indonesia Tahun 1945 (Pembukaan UUD NRI 1945) menyatakan: "... disusunlah Kemerdekaan Kebangsaan Indonesia itu dalam suatu Undang-UndangDasar Negara Indonesia yang terbentuk dalam suatu susunan Negara Republik Indonesia ...". Dalam Penjelasan UUD NRI 1945 - yang dengan Pasal II Aturan Tambahan Perubahan Keempat UUD NRI 1945 tahun 2002 dihapus - menerangkan: "Undang-Undang Dasar suatu negara ialah hanya sebagian dari hukumnya dasar negara itu. Undang-Undang Dasar ialah hukum dasar yang tertulis, ...".

Undang-Undang Dasar atau Konstitusi (ditulis dengan huruf K besar) modern pertama seperti yang dimaksud oleh Pembukaan UUD NRI 1945 danPenjelasanUUD NRI 1945 tersebut adalah Konstitusi Republik Amerika Serikat tahun 1787 (Konstitusi Amerika Serikat 1787). Konstitusi Amerika Serikat 1987 merupakan Konstitusi tertulis paling tua yang masih berlaku hingga sekarang. Para negarawan abad ke-18 yang bertemu di Philadelphia merupakan penganut konsep perimbangan kekuasaan dalam Trias Politica dariCharles de Secondat Baron de Labriede et de Montesquieu (1689-1755). Prinsip ini didukung oleh pengalaman13koloniInggris di benua Amerikabagian Utara dan diperkuat oleh ajaranJohn Locke(1632-1704) yang dikenal oleh sebagian besar delegasi. Pengaruh-pengaruh ini menimbulkan keyakinan harus didirikan tiga cabang pemerintahan yang sederajat dan sejajar, yaitu kekuasaan legislatif, kekuasaan eksekutif, dan kekuasaan yudikatif. Ketiga kekuasaan tersebut harus dibuat demikian seimbangnya, sehingga tidak ada satu pun cabang kekuasaan yang lebih berkuasa dari yang lainnya.

Ketigabelas koloni Inggris (New Hampshire, Massachusetts, Rhode Island, Connecticut, New York, New Jersey, Pencylvania, Delaware, Maryland, Virginia, North Carolina, South Carolina, dan Georgia) di benua Amerika bagian Utara tersebut, yang terbentang di sepanjang Pantai Timur daratan yang sekarang dikenal sebagai Amerika Serikat, menyatakan kemerdekaannya dari negara induknya (Britania Raya atau 
Kerajaan Inggris) tanggal 4 Juli 1776. Sebelumnya pecah perang dahsyat selama 6 tahun antara koloni-koloni tersebut melawan Britania Raya untuk memperebutkan kemerdekaan. Koloni-koloni tersebut merencanakan suatu kesepakatan untuk mengikat diri mereka sebagai suatu kesepakatan untuk mengikat diri mereka sebagai suatu bangsa. Rencana kesepakatan itu kemudian terwujud menjadi suatu perjanjian. Perjanjian itu, yang dijadikan "Pasal-pasal Konfederasi dan Uni Tetap", diterima oleh suatu kongres negara-negara bagian Amerika Serikat tahun 1777 dan ditandatangani 1778. Pasal-pasal itu menjadi bersifat mengikat setelah disahkan oleh Maryland negara bagian ke-13 pada tanggal 1 Maret 1781.

Ketigabelas koloni di benua Amerika bagian Utara yang kemudian menjadi negara-negara bagian Republik Amerika Serikat yang kini (tahun 2009) berjumlah 50 negara bagian menyatakan kemerdekaannya melalui Declaration of Independence dari Kerajaan Inggris di Philadelphia tanggal 4 Juli 1776. Tanggal ini kemudian dijadikan hari kemerdekaan Republik Amerika Serikat. Selanjutnya, di Amerika Serikatada perjuangan untuk pengakuan hak-hak asasi manusia seperti dideklarasikannya Bill of Rights tahun 1776 di negara bagian Virginia. Tanggal 1 Maret 1781 dinyatakan berlakunya The Articles of the Confederation. Tanggal 17 September 1787 disahkan/ditetapkan Konstitusi Republik Amerika Serikat tahun 1787 yang mulai berlaku tanggal 2 Juli 1789. Dengan demikian, dari berdirinya Negara Republik Amerika Serikat dan disahkan/ditetapkan Konstitusi Republik Amerika Serikat tahun 1787 terdapat jarak waktu sekitar 11 tahun.

Dalam waktu singkat, kurang dari 6 tahun kelemahan konfederasi sudah bias dirasakan. Atas dasar itulah diperlukan sebuah Konstitusi Amerika Serikat. Februari1787 Kongres kontinental yang merupakan badan legislatif negara baru itu mengirimkan suatu instruksi kepada negara-negara bagian agar mereka mengutus delegasinya ke Philadelphia untuk merevisi Pasal-pasal Konfederasi. Dokumen baru tersebut, yaitu Undang-Undang Dasar (UUD) atau Konstitusi, selesai tanggal 17 September1787 dan diterima dengan resmi tanggal 4 Maret 1789. Mukadimah UUD tersebut menyatakan: "Kami rakyat Amerika Serikat, demi membentuksuatu persatuan yang lebih sempurna, membangun keadilan, menjamin ketenangan dalam negeri, menyiapkan pertahanan umum, memajukan kesejahteraan bersama dan menjaga karunia kemerdekaan bagi diri kami dan anak-anak kami, dengan sesungguhnya mentasbihkan dan menetapkan Undang-Undang Dasar ini bagi Amerika Serikat".

Konstitusi/UUD Amerika Serikat adalah dokumen yang relatif sederhana yang menjadi "hukum tertinggi negara" ini. Ungkapan tambahan itu dibubuhkan dengan maksud agar bila UUD Negara Bagian atau undang-undang negara bagian yang disetujui oleh badan legislatifnya atau oleh Kongres Nasional ternyata bertentangan dengan UUD Federal, maka UUD atau UU tersebut menjadi tidak berlaku. 
Keputusan-keputusan yang diberikan oleh Mahkamah Agung Amerika Serikat telah mengukuhkan dan menguatkan doktrin tentang supremasi UUD ini. Wewenang terakhir tetap berada di tangan rakyat Amerika Serikat yang dapat mengadakanperubahan hukum dasar itu jika mereka mau, baik dengan mengubah UUDmaupun paling sedikit dalam teori dengan menyusun UUD baru. Namun, wewenang rakyat tersebut tidak secara langsung dilaksanakan. Perubahan besar-besaran diadakan dalam dua tahun pertama setelah UUD disahkan/ditetapkan. Pada periode itu 10 amandemen pertama yang dikenal sebagai Bill of Rights ditambahkan pada UUD. Kesepuluh amandemen tersebut mendapat persetujuan Kongres sebagai satu kesatuan pada bulan September 1789 dan disahkan oleh 11 negara bagian menjelang akhir tahun 1781. Hingga sekarang terhadap UUD/Konstitusi Amerika Serikat 1787 telah dilakukan 27 kali perubahan (amandemen). Keunggulan UUD/Konstitusi dalam mengatur pemerintahan telah membuat Amerika Serikat menjadi negara yang stabil dan maju.

\section{Pendeklarasian Hukum Konstitusi Sebagai Suatu Ilmu}

Ambruknya dan bubarnya Negara adikuasa/negara adidaya (super powerstate) Uni Soviet tahun 1991 yang diikuti oleh ambruknya atau bubarnya negara tua di Eropa Yugoslavia dan Cekoslovakia dikarenakan adanya krisis konstitusi sangat mengagetkan dunia. Begitu pula krisis konstitusi yang dialami dan dihadapi oleh banyak negara yang lain, meskipun usianya sudah puluhan tahun bahkan ratusan tahun, tetapi tetap saja negara atau negara-negara yang bersangkutan tidak beranjak dari keterbelakangan atau sukar berkembang. Malahan terus dirundung masalah, sehingga negara-negara yang tergolong disebutkan terakhir masih sebagai negara yang sedang berkembang atau bahkan negara yang masih terbelakang. Apa yang salah dengan ketiga negara (Uni Soviet, Yugoslavia, dan Cekoslovakia) atau negara-negarayanglain yang masih terbelakang itu?

Dilihat dari segi teori konstitusi berarti telah terjadi krisis konstitusi. Dalam arti, konstitusi tidak menampung secara memadai Norma Dasar (Grundnorm) atau Jiwa Bangsa (Volksgeist). Peranan konstitusi dikesampingkan, peranan penguasa melalui partai politik atau otoritarian dikedepankan. Konstitusi tidak dijadikan sebagai traktat (treaty) untuk di negara serikat. Konstitusi hanya diposisikan sebagai lambang atau catatan historis dari perkembangan suatu negara bangsa. Konstitusi sebagai hukum dasar tidak dijadikan hukum utama, hukum derajat tinggi, hukum tertinggi, dan dokumen perjanjian masyarakat pada tingkatan negara. Dampak dari itu konstitusi tidak mampu berfungsi sebagai perekat persatuan dankesatuan untuk negara-negarakesatuan atau perekat kesatuan dan persatuan untuk negara-negara serikat. Konstitusi tidak dijadikan landasan untuk hidup bersama dalam mengarungi hidup suatu negara bangsa secara damai dan penuh pengertian. Sebaliknya, konstitusi 
terus menerus diotak atik dan dipersalahkan atau bahkan diancam terus untuk diubah atau diganti bukan dihormati atau ditegakkan, sehingga yang terjadi konstitusi bukan sebagai dasar pemersatu, melainkan dianggap sebagai sumber masalah dalam mencapai cita-cita dan tujuan bersama. Ini bertentangan dengan asas hukum yang menyatakan hukum tidak sering diubah. Oleh karena kalau peraturan sering diubah bisa menurunkan martabat dan kepercayaan terhadap peraturan tadi dan dapat mengganggu kepastian hukum. Bangsa yang mengidap penyakit (kronis) krisis konstitusi tidak merasa terganggu konstitusi negara bangsanya dipersoalkan terus dan melorot atau kehilangan kewibawaannya. Mereka sudah imun atas kekisruhan yang dihadapi konstitusinya. Kalau konstitusi suatu negara bangsa dianggap sumber masalah dan kehilangan kewibawaannya kalaupun negara atau negara-negara itu tidak bubar, maka akan termasuk ke dalam kelompok negara atau negara-negara gagal.

Mengapa suatu negara atau negara-negara tergolong negara atau negara-negara modern bubar atau gagal? Ya itu tadi, suatu negara atau negara-negara menghadapi dan/atau mengalami krisis konstitusi. Hal itu disebabkan konstitusi yang dimiliki suatu negara atau negara-negara tidak menjadi bagian dari kehidupan suatu negara bangsa atau negaranegara bangsa. Hal itu disebabkan konstitusi disusun didasarkan kepentingan egoisme pembuatnya jauh dari sikap kenegarawanan, sehingga konstitusi yang dibuatnya bukan untuk negara bangsanya, melainkan hanya untuk kepentingan golongan dan untuk waktu sesaat. Atau karena pembuat konstitusi tidak cukup pengetahuan untuk membuat konstitusi. Konstitusi demikian akan terasing atau sengaja diasingkan oleh satu orang atau beberapa orang ataupun satu kelompok atau beberapa kelompok di suatu negara atau negara-negara bangsa itu untuk kepentingan diri orang atau kelompoknya. Keberadaan konstitusinya dibiarkan merana. Nilai konstitusi normatif yang ada pun dibiarkan menjadi nilai konstitusi nominal bahkan menjadi nilai konstitusi semantik. Mereka menganggap dengan cara seperti itu bukan masalah serius. Mereka beranggapan dengan kekuasaan semata semua atau sejumlah masalah yang dihadapi suatu negara bangsa atau negara-negara bangsa akan selesai. Yang terjadi justru sebaliknya kerukunan bangsa terganggu atau diredam dengan menggunakan kekuasaan otoriter. Negara bangsa yang menghadapi masalah seperti itu pertumbuhannya akan lamban dan keropos bahkan tidak jarang dilanda gerakan coup d'ètat, pronoun ciamento, putsch, separatism, people's power, atau bahkan revolution. Konstitusi yang tidak memiliki atau kehilangan kewibawaannya ada yang secara sengaja dipelihara oleh suatu rezim atau rezim-rezim semata-mata untuk kepentingan kelompok rezim yang berkuasa guna melanggengkan kekuasaannya, dengan tidak peduli apakah negara bangsanya sedang berada dijurang kehancuranatau akan tetap berada dalam keadaan tidak akan maju atau tidak akan berkembang yang penting rezimnya tetap berkuasa dan menikmati fasilitas negara. 
Dari uraian di atas dapat digambarkan tanda-tanda suatu negara mengalami atau menghadapi krisis konstitusi: (1) konstitusi tidak menampung secara memadai norma dasar (grundnorm) atau jiwa bangsa (volksgeist); (2) konstitusi tidak dijadikan sebagai traktat untuk di negara serikat; (3) konstitusi sebagai hukum dasar tidak dijadikan hukum utama, hukum derajat tinggi, hukum tertinggi, dan dokumen perjanjian masyarakat, baik di negara kesatuan maupun di negara serikat; (4) konstitusi tidak menjadi landasan pertama dan utama dalam pengaturan kehidupan kemasyarakat, berbangsa, dan bernegara; (5) konstitusi hanya menjadi hiasan/pajangan untuk disebut-sebut, tetapi senyatanya tidak dirujuk secara serius; (6) adanya upaya pengabaian atau pembiaran dari sejumlah kalangan agar konstitusi tidak bermartabat dan berlaku powerful; (7) adanya sejumlah kalangan untuk tidak melaksanakan secara sungguh-sungguh bahkan berusaha untuk mengurangi kewibawaan dan martabat konstitusi; (8) konstitusi dijadikan alat pencapaian tujuan rezimpenguasa; (9) rezimpenguasatidak memiliki komitmen secara sungguh-sungguh untukmensejahterakan rakyat dan memajukan negara; (10) rezim penguasa tidak terlalu peduli melindungi keutuhan seluruh wilayah negara; (11) rezim penguasa tidak merasa bertanggung jawab untuk melindungi seluruh bangsa; (12) rezim penguasa tidak merasa bertanggung jawab penuh untuk melaksanakan hukum secara efektif; (13) rezim penguasa tidak merasa bertanggungjawab untuk memikir-kan pekerjaan dan penghidupan layak bagi rakyat, (14) kalangan elite politik lebih me-mikirkan meraih kekuasaan daripada mengelola negara kesejahteraan; (15) adanya upaya menggradasi fungsi konstitusi dari kalangan tertentu yang berpengaruh; (16) konstitusi dijadikan oleh penguasa untuk dasar melakukan represif kepada rakyat; (17) adanya upaya mengenyampingkan konstitusi dengan dalih demokratisasi atau kepentinganbangsa dan negara; (18) adanya upaya dari kalangan tertentu untuk mengubah bukan menegakkan konstitusi; (19) adanya upaya dari kalangan berpengaruh agar konstitusi tidak berfungsi sebagaimana mestinya, (20) adanya golongan yang mengubah konstitusi yang tidak berjiwa negarawan; (21) perubahan konstitusi tidak menampung dan mencerminkan jiwa atau jatidiri bangsa, serta (21) konstitusi tidak dijadikan sumber solusi masalah kenegaraan/ketatanegaraan.

Salah satu cara mengatasi krisis konstitusi adalah menjadikan materi muatan hukum konstitusi sebagai jabaran norma dasar atau jiwa bangsa. Selanjutnya, mengembalikan konstitusi sebagai hukum dasar dijadikan hukum utama, hukum derajat tinggi, hukum tertinggi, atau dokumen perjanjian masyarakat. Untuk mengembalikan atau memposisikan konstitusi ke kedudukan seperti itu, maka perlukonstitusi dipahamioleh segenap warga bangsa atau warga negara dari negara yang bersangkutan bahwa untuk menjamin kehidupan bersama agar dapat berjalan damai dan maju, maka konstitusi harus berada pada posisi wibawa. Untuk itu pengetahuan dan keilmuan mengenai konstitusi secara masif dipahami oleh segenap warga bangsa atau warga negara terutama oleh kalangan 
menengah ke atas teristimewa para elite politik dan pimpinan negara atau pimpinan pemerintah dan pimpinan pemerintah daerah. Untuk segenap warga bangsa atau warga negara terutama mereka yang tergolong ilmuwan kenegaraan/ketatanegaraan memahami konstitusi penting dalam menjamin persatuan dan kesatuan untuk negara kesatuan atau kesatuan dan persatuan untuk negara serikat dan memajukan negara bangsa, maka harus ada usaha yang mengembangkan keilmuan hukum konstitusi dan ilmu hukum konstitusi.

Dengan berkembangnya keilmuan hukum konstitusi dan ilmu hukum konstitusi, maka akan ditemukan pemikiran, konsepsi, penelitian, teori, ilmu, pendekatan, metodologi, sistem, politik, asas, asas peraturan, norma, peraturan, pembentukan, penerapan, empiris, putusan, dan pelaksanaan hukum konstitusi. Dalam keadaan dan untuk mengatasi hal itu, maka Prof. Dr. Drs. Astim Riyanto, SH, MH. mendeklarasikan Hukum Konstitusi Sebagai Suatu Ilmu tanggal 6 Agustus 2007 di depan suatu komunitas akademisi di suatu Universitas di Indonesia. Melalui terbentuknya Ilmu Hukum Konstitusi banyak pihak terutama ilmuwan kenegaraan/ketatanegaraan ditantang untuk dapat mengembangkan ilmu hukum konstitusi sebagai sarana pembangunan masyarakat madani. Para ilmuwan ilmu hukum konstitusi ditantang untuk mengembangkan ilmu hukum konstitusi serta menemukan atau membuat teori-teori, paradigma-paradigma, dan model-model solusi masalah dari sudut pandang konstitusi yang dapat dijadikan rujukan dalam solusi masalah kenegaraan/ketatanegaraan. Dengan cara demikian suatu negara bangsa atau negara-negara bangsa akan terhindar dari kemelut yang tidak perlu, sebaliknya suatu negara bangsa atau negara-negara bangsa dapat memecahkan masalah kenegaraan/ketatanegaraan dan negara bangsaitu dapat menjamin kehidupan stabil, maju, damai, nyaman, tenteram, dinamis, adil, dan sejahtera.

\section{Penutup}

Dengan kemunculan Ilmu Hukum Konstitusi (Science of The Law of The Constitution) dalam khasanah ilmu hukum, maka akan memberi perspektif dan ruang baru dalam penelitian hukum, sistematika ilmu hukum, pengkajian ilmu hukum, paradigma ilmu hukum, pendidikan hukum, dan langkah-langkah pengembangan ilmu hukum. Sudah tentu kemunculan ilmu baru ini akan member konstribusi signifikan bagi tegaknnya negara konstitusional dan pemerintahan konstitusional dalam penegakan negara hukum kesejahteraan (materiele Rechtsstaat, material Rule of Law, atau material Law State). 


\section{Daftar Pustaka}

Aristotle. Politics, Translated by Sir Ernest Barker, Revised with an Introduction and Notes by R.F. Stalley, First Published 1995, Reisseud 1998. New York: Orford University Press Inc., 1998.

Riyanto, Astim. Teori Konstitusi, Cetakan Keempat, Cetakan Pertama 1993, Bandung: Yapemdo, 2009.

Bandung: Yapemdo, 2009.

Filsafat Hukum, Cetakan Ketiga (Cetakan Pertama 2003), Bandung: Yapemdo, 2010.

Manan, Bagir. Pertumbuhan dan Perkembangan Konstitusi Suatu Negara, Bandung: CV. Mandar Maju, 1995.

Dicey, Albert Venn. "An Introduction to Study of The Law of The Constitution", Tenth Edition, First Edition 1885, London: English Language Book Society and Macmillan, 1952.

Martosoewignjo, R. Sri Soemantri, Prosedur dan Sistem Perubahan Konstitusi, Cetakan IV Cetakan I 1978, Bandung: PT. Alumni, 1987.

Strong, C.F. Modern Political Constitutions An Introduction to the Comparative Study of Their History and Existing Form, Fifth Revised Edition 1958, Second Impression First Printed 1930, London: Sidgwick \& Jackson Limited, 1960.

Wheare, Kenneth C. Modern Constitutions, Third Impression, First Published 1951, London: New York, Toronto, Oxford University Press, 1975.

\section{Makalah}

Astim Riyanto, Hukum Konstitusi Bagian Dari Hukum Tata Negara, Makalah, Dipresentasikan di depan komunitas akademisi Fakultas Pendidikan Ilmu Pengetahuan Sosial (FPIPS) Universitas Pendidikan Indonesia (UPI) dalam rangka Dr. Astim Riyanto, SH, MH. memperoleh Jabatan Guru Besar Tetap dalam Bidang Ilmu Hukum Tata Negara spesialisasi Hukum Konstitusi, FPIPS UPI, Bandung, 6 Agustus 2007.

Pengukuhan Jabatan Guru Besar Tetap Dr. Drs. Astim Riyanto, SH, MH. dalam Bidang Ilmu Hukum Tata Negara spesialisasi Hukum Konstitusi pada Fakultas Pendidikan Ilmu Pengetahuan Sosial (FPIPS) Universitas Pendidikan Indonesia (UPI), Bandung tanggal 22 Oktober 2008. 


\section{Peraturan Perundang-undangan}

Undang-Undang Dasar Negara Republik Indonesia Tahun 1945, Lembaran Negara 1959 Nomor 75.

Perubahan Pertama Undang-Undang Dasar Negara Republik Indonesia Tahun 1945, Ditetapkan oleh Majelis Permusyawaratan Rakyat RI di Jakarta tanggal 19 Oktober 1999.

Perubahan Kedua Undang-Undang Dasar Negara Republik Indonesia Tahun 1945, Ditetapkan oleh Majelis Permusyawaratan Rakyat RI di Jakarta tanggal 18 Agustus 2000.

Perubahan Ketiga Undang-Undang Dasar Negara Republik Indonesia Tahun 1945, Ditetapkan oleh Majelis Permusyawaratan Rakyat RI di Jakarta tanggal 9 November 2001.

Perubahan Keempat Undang-Undang Dasar Negara Republik Indonesia Tahun 1945, Ditetapkan oleh Majelis Permusyawaratan Rakyat RI di Jakarta tanggal 10 Agustus 2002.

Undang-Undang Republik Indonesia Nomor 12 Tahun 2011 tanggal 12 Agustus 2011 tentang Pembentukan Peraturan Perundang-undangan (Lembaran Negara RI 2011 No. 82, Tambahan Lembara Negara RI No. 5234). 